\title{
Periprostetik enfeksiyonlarda peroperatif tanı yöntemleri
}

\author{
Peroperative diagnostic methods of periprosthetic infections
}

\author{
Selami Çakmak
}

GATA Haydarpaşa Eğitim Hastanesi, Ortopedi ve Travmatoloji Kliniği, İstanbul

\begin{abstract}
Periprostetik eklem enfeksiyonları artroplasti ameliyatlarının önemli komplikasyonlarından biri ve ciddi morbidite nedenidir. Tanının doğru konulması ve enfeksiyona neden olan etkenin doğru tespit edilmesi tedavinin de etkin yapılamasına olanak verir. Bu derlemede, periprotez eklem en-feksiyonunun tanısında, ameliyat esnasında ve ameliyattan sonraki dönemde, klinisyene yardımcı olabilecek yöntemler ayrıntılı olarak değerlendirilmiştir. Periferik kan testlerinin yanı sıra, sinoviyal sıvı ve eklem içi dokunun çeşitli histopatolojik, serolojik ve moleküler yöntemlerle değerlendi-rilmesi, enfeksiyonun ayırıcı tanısında oldukça değerli bilgiler vermektedir. Ağrılı protezin nedeninin ayırıcı tanısında, anamnez, fizik muayene, CRP ve sedimentasyon tetkikleri ilk basamak iken, eklem sıvısının aspirasyonu ile örneklem ikinci ve önemli bir basamaktır. Klinik şüphe devam ederken halen tanı konulamamış ise, eklem aspirasyonu tekrarlanmalı veya doku biyopsisi yapılmalıdır. Ameliyat esnasında görülen pürülan sıvının başlangıçta doğrudan bir enfeksiyon göstergesi olduğu kabul edilirken, özellikle metal-metal protezlerde de görülmesi, pürülan sıvı görülmesini tanı kriterleri arasından çıkarmıştır. Serum lökosit sayısı ile gram boyamanın zayıf bir belirteç ve bunun yanında ciltte protezle ilişkili bir sinus varlığının ise enfeksiyonun net bir bulgusu olduğu vurgulanmıştır.
\end{abstract}

Anahtar sözcülkler: periprostetik enfeksiyon; peroperatif; serolojik; eklem aspirasyonu

\begin{abstract}
Periprosthetic joint infections are one of the significant complications of arthroplasty and associated with serious patient morbidity. Accurate diagnosis and precise isolation of the pathogenic microorganism is the critical corner stone of efficient treatment. In this review, peroperative diagnostic methods which serve the physician in the pathway of diagnosis are assessed in detail. In addition to peripheral blood tests, a variety of serological, histopathological and molecular methods of synovial fluid and joint tissue gives valuable information to evaluate the differential diag-nosis of infection. In the differential diagnosis of painful prosthetic joint history, physical examination, CRP and sedimentation tests are initial steps. The second and important step is aspiration of synovial fluid from infected joint. If there is still an undiagnosed clinical suspicion, joint aspiration should be repeated or tissue biopsy should be performed. Recognizing the purulent fluid while doing surgery was previously one of the major markers of infection, but this opinion has changed nowadays because of the purulent fluid appearance seen in some revisions of metal-onmetal articulations. It has been understood that the serum leukocyte level and gram staining methods are weak signs of infection while a sinus tract connected with prosthesis is a major indicators.
\end{abstract}

Key words: periprosthetic infection; peroperative; serologic; joint aspiration eriprostetik enfeksiyonlar (PPE) total eklem artroplastisi ameliyatlarından sonra görülen komplikasyonlar arasındaki önde gelen yerini halen muhafaza etmektedir. Primer kalça ve diz artroplastilerinden sonraki iki yıl içinde \%1-2 oranında görülen PPE oranı, revizyon protez cerrahisi sonrası \%7'lere ulaşmaktadır. Gelişen materyal türleri ve cerrahi tekniklerle sağkalımı daha uzun hal almakta olan total eklem artroplasti ameliyatları, beraberinde PPE sayılarını da arttırmaktadır. ${ }^{[1,2]} \mathrm{Bu}$ nedenle, PPE ile aseptik gevşeme gibi diğer başarısızlık nedenlerini ayırt etmek oldukça önem arz etmektedir.

PPE tanısının doğru konulması tedavi stratejisinin de doğru ve etkin yürütülmesini sağlayacaktır. Ancak, doğru tanı konulmasına yönelik henüz standartlaşmış bir yöntem ortaya konulamamış ve bir olguya PPE denilebilmesi için gereken klinik ve laboratuvar kriterleri de tam olarak tanımlanamamıştır. ${ }^{[3]}$ Ekonomik açıdan da birçok kayba yol açan ve giderek büyüyen bu sorunun çözümüne yönelik çeşitli yol haritaları ve testler

- İletişim adresi: Doç. Dr. Selami Çakmak, GATA Haydarpaşa Eğitim Hastanesi, Ortopedi ve Travmatoloji Klini-ği, Tıbbiye Cad. Selimiye Mah. Üsküdar, İstanbul Tel: 0505 - 7745830 e-posta: selamicakmak@gmail.com

- Geliș tarihi: 1 Mart $2016 \quad$ Kabul tarihi: 1 Mart 2016 
öne sürülmüştür. Bu yol haritalarından günümüzde en yaygın kabul görenler, Amerikan Ortopedik Cerrahlar Birliği (AAOS-American Academy of Orthopaedic Surgeons) tarafından 2010 yılında ve sonrasında da Kas-iskelet Enfeksiyon Birliği (MSIS-MusculoSkeletal Infection Society) tarafından 2011 yılında yayımlanmış olanlardır. ${ }^{[4,5]}$ Bunların her ikisi de belirli fizik muayene bulguları, kanda ve/veya eklem sıvısı aspirasyonunda yapılan bir takım laboratuvar testleri ışığında periprotez enfeksiyon tanısı konulmasını ve tanıya uygun tedavi tedaviye yönelik klinisyenlere rehberlik etmeyi hedeflemektedir. Bu tanımlamaların bir diğer hedefi de, bilimsel araştırma ve yayınlarda kullanılacak ortak terminolojinin oluşturulması ve karşılaşılan herhangi bir klinik tablo karşısında ortak dilin kullanılmasıdır. Bu çalışmalardan en güncel ve kabul göreni olan Periprostetik Eklem Enfeksiyonu için Uluslarası Mutabakat Toplantısı, sonuçları yayımlanmış olan rehber niteliğinde bir belge$\operatorname{dir}^{[6]}$

Peroperatif PPE tanısında ilk adım şüphesiz ki anamnez, fizik muayene ve direkt radyografik görüntülemedir. Ancak, çoğu kez tanı için bu adımlar yeterli olmaz ve ileri laboratuvar testleri gerekir. Çünkü PPE hastaları, klasik enfeksiyon bulguları olan ateş, kızarıklık, titreme gibi bulgularla değil, ağrı ve fonksiyon kaybı şikayetleri ile başvurur. PPE tanısında kullanılmakta olan bu yöntemleri alt başılıklar altında inceleyelim:

\section{PERIFERIK KAN TESTLERi}

- Lökosit sayımı

- CRP ve sedimentasyon

PPE için iyi bir tarama testi olan bu serolojik belirteçlerin ağrılı total diz protezi değerlendirilmesinde ilk adım olarak uygulanması gerektiği bildirilmiştir. ${ }^{[7]}$

\section{- Prokalsitonin, Fibrinojen}

İnflamasyon esnasında salınan bu proinflamatuvar belirteçlerin eritrositlerin birbirine yapışmasına neden olduğu ve böylelikle sedimentasyon oranını arttırdığı düşünülmektedir. ${ }^{[8]}$

\section{- IL-6}

Makrofajlardan salınan bu belirteçin akut inflamasyon esnasında karaciğerden CRP salınımını düzenlediği düşünülmektedir.

\section{GRAM BOYAMA}

Rutinde sık kullanılmakla beraber duyarlılı̆̆ \%27 olarak bildirilmiştir. ${ }^{[9]}$ PPE tanısındaki rolü azdır. ${ }^{[10]}$ Yeni moleküler tanı yöntemlerinin gelişmesi ile, rolü giderek azalmaktadır.

\section{DONDURULMUŞ KESIT (FROZEN SECTION)}

Dondurulmuş kesit yöntemi, ameliyat esnasında alınan doku örneğinin patoloji bölümünde kısa sürede incelenmesi ile, ameliyat devam ederken cerrahı bilgilendirebilen önemli bir yöntemdir. ${ }^{[11]}$ Eksi $20^{\circ} \mathrm{C}$ 'de dondurularak kesit alınan doku parçalarının incelenmesinin avantajı, 20 dakika gibi bir sürede hızlı sonuç vermesidir. Böylelikle, bu intraoperatif histolojik inceleme nedene yönelik bilgi verebilir. İncelemede makrofaj yoğunluğunun fazla olması halinde, osteoliz tanısı ön planda düşünülür. Lenfosit ve/veya plazma hücresi hakimiyeti kronik bir enfeksiyon, nötrofil hakimiyeti ise akut enfeksiyon göstergesi olabilir. Örnekler mutlaka psödokapsülden ve/veya periprotez membrandan alınmalıdır. Örneklerin elektrokoter kullanılarak alınmaması gerekir. ${ }^{[7]}$ Ayrıca, örneklerin doğru alınması ve tanıda yanlış pozitif sonuçların ortaya çıkmaması amacıyla, kemiğin içinden kazınarak doku alınmaması gerekir. Böylelikle, kemik iliği içinden kazıma ile gelebilecek nötrofillerin hücre sayımını etkilememesi sağlanır.

PPE tanısının konulabilmesi için, her büyük büyütme alanında (HPF-High Power Field) beşten fazla nötrofil olması veya $400 \times$ büyütme ile 10 'dan fazla nötrofil bulunması gereklidir (beş ayrı alan sayılarak). ${ }^{[7,12]}$

Dondurulmuş kesit yönteminin etkinliğini araştıran bir çalışmada, ameliyat sonrasında formalinle tespit edilmiş doku kesitleri bulguları ve dondurulmuş kesit ile elde edilen bulguların \%97 oranında uyumlu olduğu bulunmuştur. ${ }^{[13]}$ Ancak, uyum oranının düşük olduğunu bildiren yayınlar da mevcuttur. ${ }^{[14]}$ Dondurulmuş kesitte oluşabilecek artefaktların formalinle tespit etme yöntemine göre daha fazla görülmesi de, bu yöntemin dezavantajıdır. ${ }^{15]}$ Ayrıca virülansı düşük etkenlerde, özellikle de giderek yaygınlaşmakta olan omuz protezi vakalarında görülen Propionibacterium acnes patojeninde etkisi zayıftır.

Ameliyat esnasında doku örneğini alan cerrah ile dokunun histopatolojik incelemesini yapan patolog arasındaki bilgi paylaşımının oldukça önemli olduğu da, akıldan çıkarılmaması gereken hususlardandır.

\section{GERÇEK ZAMANLI POLIMER ZINCIR REAKSIYONU -PZR \\ (REAL TIME - POLYMERASE CHAIN REACTION, RT-PCR)}

Ameliyat esnasında alınan kültür örneklerinin duyarlılık ve özgüllüğünün optimal olmaması nedeniyle, son yıllarda, PPE tanısında moleküler tanı yöntemleri ve bunların başında da PZR yöntemlerinin kullanılması öne çıkmıştır. ${ }^{[3,16]}$ Enfeksiyona neden olan etkenin saptanmasında, patojenin gen dizilimine özgü 
floresan belirteçler kullanılmaktadır. Ameliyat esnasında alınan kültürlere göre duyarlılı̆ı daha yüksektir (\%86). ${ }^{[17]}$ Özgüllüğü ise değişkendir (\%0-100) ve dolayısıyla yanlış pozitif sonuç yaygındır. Moleküler yöntemlerin en önemli avantajı, mikroorganizmanın tespiti için aktif çoğalma veya büyümenin gerekli olmayışıdır. Avantajlarından birisi de, sonuçların devam etmekte olan antibiyotik tedavisinden etkilenmemesidir. ${ }^{[18]}$ Ayrıca bu, antibiyotik direnci ile ilgili bilgi verebilir ve genlerin tanımlanmasında yararlı olabilir. Klinik tablo ile enfeksiyon şüphesinin yüksek olduğu, ancak kültür ve diğer tanısal testleri negatif çıkmış olgular$\mathrm{da}$, sonikasyonlu/sonikasyonsuz yöntemle patojenin tanımlanmasında oldukça yararlı olabilir. Yine de, PZR yönteminin PEE tanısındaki yerini netleştirmek amacıyla, yüksek kanıt düzeyine sahip yeni çalışmalara ihtiyaç olduğu vurgulanmıştır. ${ }^{[19]}$ Maliyet açısından da yüksek olan bu testin maliyet etkinliğinin belirlenmesi amacıyla da, yeni çalışmalara ihtiyaç vardır.

\section{SINOVIYAL SIVI BELIRTEÇLERI}

\section{Lökosit Sayımı}

PPE için gerekli sinoviyal sıvıdaki lökosit sayısının eşik değeri, akut enfeksiyonlarda ( $<6$ hafta) 10 bin hücre/ mikrolitre ve kronik enfeksiyonlarda ( $>6$ hafta) 3 bin hücre/mikrolitre olarak kabul edilmektedir. Bunun yanı sıra, eşik değerin kalça artroplastisinde 4200 hücre/mikrolitre (veya $>\% 80 \mathrm{PMNL}$ ) ve diz artroplastisinde 1700 hücre/mikrolitre (veya \%65 PMNL) olduğunu bildiren yayınlar da mevcuttur. ${ }^{[20,21]}$ Bu belirteçin duyarlılığı ve özgüllüğü yüksektir. ${ }^{[22]}$ Laboratuvarda analizinin kolay olması, en önemli avantajıdır. Ancak, eklem içi genel inflamasyonu gösterir. Inflamatuvar artrit veya kristal artropatisi ile enfeksiyon halini ayırt etmeye yardımcı olmaz. Özellikle kültürün negatif olduğu olgularda pozitif olması halinde, PPE tanısındaki rolü önemlidir.

\section{IL-6}

T hücre ve makrofajlarca salınan bu sitokinin, inflamasyonu düzenleyici rolü olduğu bilinmektedir. Bu belirteçin duyarlılığının \%87-90, özgüllüğünün ise \%95100 olduğu bildirilmiştir. ${ }^{[23,24]}$ Enfekte total diz protezinin iki aşamalı revizyonu sonrasında re-implantasyon zamanının uygunluğu konusunda yararlı olabileceği bildirilmiştir, ancak kanıt düzeyi yeterli değildir. ${ }^{[25]} \mathrm{Bu}$ belirteçin dezavantajı, her merkezde çalışılamaması ve pahalı olmasıdır.

\section{Alfa-defensin}

Bakteri varlığında nötrofillerden salınan bir protein olan alfa-defensinin tanıdaki duyarlılı̆g $\% 97-100$, özgüllüğü ise \%96-97 olarak bildirilmiştir (eşik değer $5,2 \mathrm{mg} / \mathrm{ml}) \cdot{ }^{[26,27]}$ Bu teste sinoviyal CRP testi de eklenirse, özgüllük \%100'e çıkabilir. ${ }^{[28]} \mathrm{Bu}$ belirtecin, diğerlerine göre, ameliyat öncesi başlanmış antibiyotik devam ederken ve sistemik inflamatuvar artriti olan hastalarda kullanılabilme avantajı vardır. Çünkü, çalışılan örnek doğrudan sinoviyal sıvıdır ve sistemik değil lokalize bir göstergedir. Ayrıca, şu anda ticari bir ürün olarak bulunmaktadır. ${ }^{[26,29]}$

\section{CRP}

Sinoviyal CRP değerinin $>9,5 \mathrm{mg} / \mathrm{L}$ olması halinde, PPE tanısındaki duyarlılığının \%85, özgüllüğünün ise \%95 olduğu bildirilmiştir. ${ }^{[30]}$ Ancak, sinoviyal sıvıda CRP çalışılması için, laboratuvar ile irtibat halinde olunması gerekir. Çünkü, serum CRP için kalibrasyonu yapılmış otomatik ölçüm cihazları ile doğru sonuç alınamayabilir.

\section{Lökosit Esteraz}

Nötrofillerin içinde yer alan lökosit esterazın nötrofillerin parçalanması ve açığa çıkması ile sinoviyal sıvıdaki lökosit sayısı tahmin edilebilir. Bu amaçla, rutinde idrar tahlilinde kullanılan strip test çubuklarındaki lökosit esteraz bölümü kullanılabilir. Bu çabuk ve ucuz yöntemin sonuçları kültür sonuçları ile karşılaştırılmış ve duyarlılı̆ı \%93,3 özgüllüğü ise \%77 olarak bulunmuştur. Ancak, testi yaparken örneklem kanlı ise, santrifüj yapıldıktan sonra testin yapılması güvenilirliliğini arttırmaktadır. ${ }^{[31]}$

\section{Diğerleri}

HBD-2 ve HBD-3 (Human Beta-Defensin) de nötrofillerden salınan ve özellikle gram negatif bakteriler ve Candida'ya karşı etkin belirteçlerdir. LL-37 (Cathelicidin LL-37) ve HBD-3'ün, PPE tanısı alan hastalardan alınan eklem aspirasyon örneklerinde, aseptik örneklere göre anlamlı derecede yüksek oranda saptandığı gösterilmiştir. ${ }^{\left[{ }^{32}\right]}$ Enfeksiyonun aktif olduğu eklem sIvısında, makrofajlardan salınan sitokinler (IL1beta, IL-6, IL-8, IL-17), alfa-2-makroglobulin, TNFalfa, IFN-gama ve VEGF de artmış olarak bulunabilir, ancak bu belirteçlerin romatoid artrit gibi diğer inflamatuvar eklem hastalıklarında da artabileceği unutulmamalıdır. ${ }^{[33]}$

\section{KÜLTÜR}

Serolojik parametreler ile tanıda sonuca varılamamış ve klinik tabloya göre enfeksiyon şüphesi hala kuvvetli ise, eklemden alınacak sıvı veya doku örnekleri ön planda yer alır. Patojen etken üretilinceye kadar, antibiyotik tedavisine başlanılmaması gerektiği önerilmektedir. 

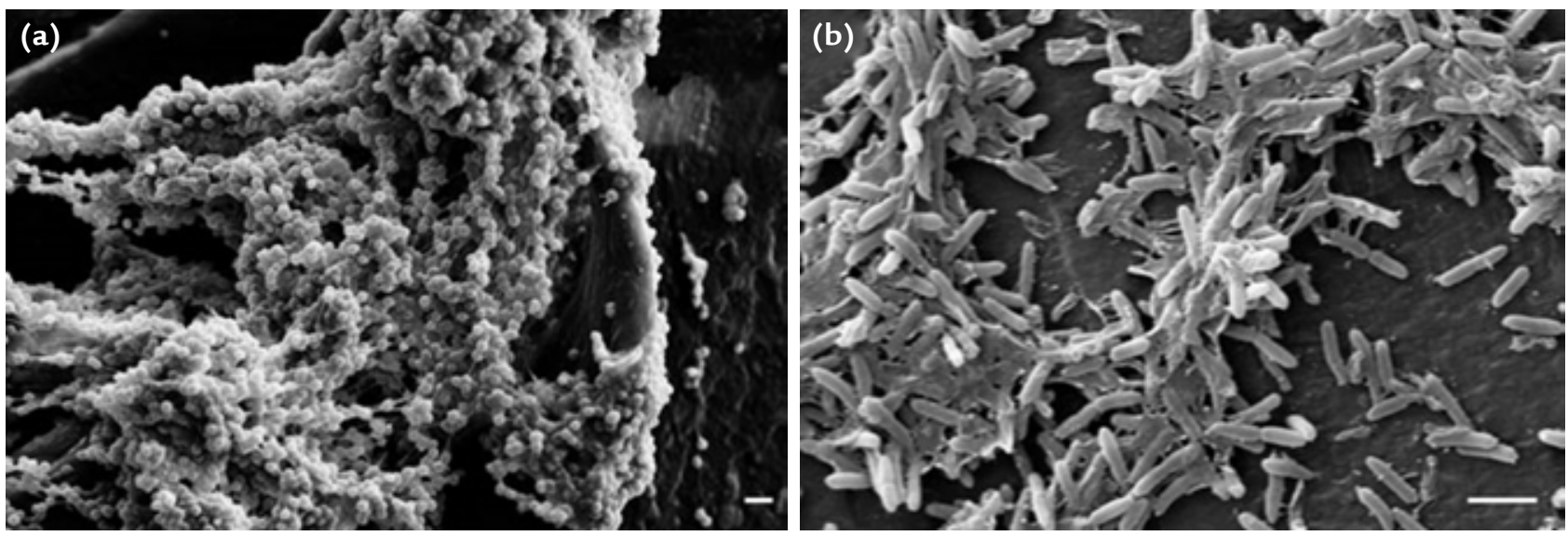

Şekil 1. a, b. S.epidermidis (a) ve P.aeruginosa (b) bakterilerinin implant polietilen materyal üzerinde 48 saatte oluşturmuş olduğu biyofilm tabakasının elektron mikroskobik görüntüsü. (Cakmak S, Bichara D, Kantarci A, Hasturk H, Nguyen D. Vitamin E Doped Highly Cross-Linked (HXL) UHMWPE Demonstrates Lower S. epidermidis and P. Aeruginosa Adherence Compared to HXL Virgin UHMWPE. 2014 ORS Annual Meeting, Poster no:1140)

Aksi halde, mikroskopinin duyarlılı̆̆ \%72'den \%27'e düşmektedir. Ancak, ameliyat öncesi verilecek tek doz profilaktik antibiyotiğin kültür sonuçlarını etkilemediği gösterilmiştir. ${ }^{[7]}$ Yara sürüntü kültürü veya sinus yolu ağzından alınan sürüntü kültürü, sonuçları tanıda yanılgıya neden olmaktadır. Eklem içinden alınan dokunun kültür sonucu ile korelasyonu \%47 oranında bulunmuştur. Dolayısıyla, bu durum gerçek patojene etkili olmayarak, gereksiz ve uygun olmayan antibiyotik kullanılmasına yol açabilir.

Mutlaka, doku örneği ve sinoviyal sıvı örneği alınarak kültüre gönderilmelidir. Bu örneklerin üçten az ve altıdan fazla olmaması gerektiği önerilmektedir. Doku örneği alınırken elektrokoter kullanılmaması ve örneğin keskin disseksiyon ile alınması oldukça önemlidir. Alınan örneklerin laboratuvara uygun kültür tüplerinde gönderilmesi ve mutlaka hem aerobik hem de anaerobik mikroorganizmlar açısından kültüre edilmesi de, tanı yolunda gereken hususlardandır. Bu aşamada pediatrik kan kültürü tüplerinin kullanılması, daha tutarlı sonuçlar verebilir.

Çıkarılmış protezin sonikasyonu ile elde edilen örneğin kültüre alınması, etkeni saptama açısından yararlı olabilir. Sonikasyon işlemi, protez üzerinde yapışarak bir tabaka halinde biyofilm oluşturmuş olan mikroorganizmayı tespit etmekte yol göstericidir. Ancak, uygulanacak antibiyotik tedavisi biyofilm içinde korunmuş haldeki bu patojenlere etkili olamayacak, sadece ortamdaki serbest mikroorganizmlara karşı savaşacaktır. Bu nedenle, rutinde uygulanması henüz önerilmemekte ve bu konu daha ileri araştırmalar gerektiren bir alan olarak görülmektedir. Yine de, ameliyattan önce pozitif kültür sonucuna ulaşılamamış, ameliyat öncesi iki hafta süreyle antibiyotik tedavisi almakta olup enfeksiyon şüphesi halen kurvetli olan ve özellikle de daha önce farklı ve çoklu antibiyotik kullanım öyküsü olan (yani polimikrobiyal etkenlerin rol oynadığı) olgularda uygulanması önerilmektedir.

Rutin kültür inkübasyon süresi 5-14 gündür, ancak düşük virulanslı bakteri şüphesi varsa (cerrahi öncesi patojen üretilememiş, ancak klinik enfeksiyon şüphesi yüksekse) bu süre 14 günü geçmelidir. Genellikle, ilk birkaç gün içinde çoğu bakteri izole edilir. Bağışıklık sisteminin baskılanmış olduğu ve klinik olarak enfeksiyon şüphesinin yüksek, ancak kültürle etkenin üretilemediği durumlarda, mikobakteriler ve mantar açısından da kültür yapılmalıdır. ${ }^{[5]}$

Ameliyat esnasında alınan örneklerde, kültür ile pozitif sonuç alınamama oranı \%2-18 arasında değişmektedir. Bu yanlış negatif sonucun nedeni olarak birkaç görüş öne sürülmüştür: patojenin biyofilm oluşturma kapasitesi olan bir etken olması; ameliyat esnasında devam etmekte olan antibiyoterapi; kültür için seçilen besiyerinin uygun olmaması; kültürde inkübasyon süresinin yetersiz olması.

\section{SONIKASYON VE BIYOFILM AYRIŞTIRMASI}

Çoğu periprostetik enfeksiyon, bir yıl içinde gelişmektedir. İmplant-mikroorganizma yapışması ile zaman içinde olgunlaşan bir matriks, giderek biyofilm adı verilen ve bakterileri içinde barındıran ağımsı bir yapıya dönüşür. Şekil 1'de S.epidermidis ve P.aeruginosa bakterilerinin oluşturmuş olduğu biyofilm tabakalarının elektron mikroskopik fotoğrafı görülmektedir. Polisakkarit ve protein matriksten oluşan bu biyofilm 
tabakası, patojeni, antimikrobiyal ajanlara ve minimal inhibitör konsantrasyona karşı 1000 kat daha dirençli hale getirebilir. ${ }^{[34]}$ Eklem protezi varlığında bu riskin 100 kat arttığı gösterilmiştir. ${ }^{[35]}$ Sonuçta, biyofilmin implanttan ayrılmasını sağlamak için, implantın sonikasyon yöntemine tabi tutulması gerekir. ${ }^{[36]}$

\section{SONUÇ}

AAOS 2010 raporunda, ameliyat sonrasında açıklanmayan ağrısı olan hastada, öncelikle periferik kanda CRP ve sedimentasyon tetkikleri ve eklem aspirasyonu yapılması önerilmektedir. Aspirasyon sıvısı en az 14 gün kültüre edilmeli ve lökosit sayısı ile nötrofil yüzdesine bakılmalıdır. Bunların eşik değerleri ile ilgili farklı sonuçlar bildiren yayınlar olmakla birlikte, genellikle kabul değerler şu aralıklardadır: 1700-10700 lökosit/mikrolitre ve \%65-89 PMNL. ${ }^{[20,21,37-39]}$ Klinik olarak enfeksiyon şüphesinin yüksek ve sürüntü kültüründe üremenin olduğu, ancak aspirasyon sıvısında kültürün negatif olduğu durumlarda ise, eklem aspirasyonun tekrarlanması veya eklem biyopsisi yapılması da diğer önerilerdir. [10,21,37,38,40,41] Tanı aşamasında üçüncü basamak olarak, işaretli lökosit ve galyum sintigrafisi, zayıf-orta kanıt düzeyi ile önerilmektedir. Özellikle ağrılı kalça protezinin septik-aseptik ayırımında, FDG-PET'in (FluoroDeoxyGlucose-Positron Emission Tomography) umut verici ve doğru bir tanı araCı olabileceği de bildirilmiştir. ${ }^{[42]}$

Uluslararası Periprostetik Eklem Enfeksiyonları Ortak Görüş Toplantısı'nın kanıta dayalı ortak mutabakat raporunda, PPE tanısının konulabilmesi için aşağıdaki üç ana kriterden birinin varlığının gerekli olduğu belirtilmiştir ${ }^{[6]}$ :

1. Protez ile ilişkili bir sinus varlığı.

2. Etkilenen protezli eklemden alınan doku veya sinoviyal sıvı örneklerinin en az ikisinde kültür ile bir patojenin saptanmış olması.

3. Aşağıdaki altı minör kriterden üçünün varlığı:

a. Serum C-reaktif protein (CRP) ve sedimentasyon artışı.

b. Sinoviyal sıvıda lökosit sayısında artış VEYA lökosit esteraz strip testi $(++)$ olması. ${ }^{*}$

c. Sinoviyal sıvıda nötrofil yüzdesinde (\%PMNL) artış. ${ }^{\prime}$

d. Periprostetik dokunun pozitif histolojik analizi.

e. $400 \times$ büyütmede, 5 HPF'de beşten fazla nötrofil olması.

f. Etkilenen eklemden alınan doku veya sinoviyal sıvı örneklerinin birinde kültür ile patojenin saptanması.

* Lökosit sayısı için eşik değer mikrolitrede 1100-1700 hücre

\# Nötrofil yüzdesi için eşik değer \%65 ${ }^{[43,44]}$
Ancak, düşük virülanslı organizmaların (Propionibacterium acnes gibi) enfeksiyonunda, bu kriterler görülmeden enfeksiyon oluşabilir. ${ }^{[45]}$

Sonuçta, gram boyama ve serum lökosit sayısının PEE için zayıf belirteçler olduğu söylenebilir. İlginç olan, pürülan sıvı görülmesi ile ilgili husustur. Her ne kadar Kas-i̇skelet Enfeksiyon Birliği (Musculoskeletal Infection Society) ve Amerika Enfeksiyon Hastalıkları Birliği (Infectious Disease Society of America) raporlarında PPE açısından olması gereken bir bulgu olarak bildirilmiş olmasına rağmen, Uluslararası Periprostetik Eklem Enfeksiyonları Ortak Görüş Toplantısı'nın 2013 yılındaki raporunda, pürülan sıvı görülmesinin enfeksiyonun kesin göstergesi olmadığı vurgulanmıştır. Özellikle son yıllarda, metal-metal protezlerin revizyonları esnasında pürülan sıvı görülmesi, ayırıcı tanıda dikkatli olunması gerektiğini göstermektedir. Oluşan pürülan sıvının alerjik reaksiyona bağlı olabileceği de vurgulanmaktadır. Tüm bunların yanında, ciltte görülen bir sinus yolu enfeksiyonunun kesin göstergelerinden biridir.

\section{KAYNAKLAR}

1. Kurtz SM, Ong KL, Lau E, Bozic KJ, Berry D, Parvizi J. Prosthetic joint infection risk after TKA in the Medicare population. Clin Orthop Relat Res 2010;468(1):52-6. Crossref

2. Ong KL, Kurtz SM, Lau E, Bozic KJ, Berry DJ, Parvizi J. Prosthetic joint infection risk after total hip arthroplasty in the Medicare population. J Arthroplasty 2009;24(6 Suppl):105-9. Crossref

3. Parvizi J, Adeli B, Zmistowski B, Restrepo C, Greenwald AS. Management of periprosthetic joint infection: the current knowledge: AAOS exhibit selection. J Bone Joint Surg Am 2012;94(14):e104. Crossref

4. Parvizi J, Della Valle CJ. AAOS Clinical Practice Guideline: diagnosis and treatment of periprosthetic joint infections of the hip and knee. J Am Acad Orthop Surg 2010;18(12):771-2.

5. Parvizi J, Zmistowski B, Berbari EF, Bauer TW, Springer BD, Della Valle CJ, Garvin KL, Mont MA, Wongworawat MD, Zalavras CG. New definition for periprosthetic joint infection: from the Workgroup of the Musculoskeletal Infection Society. Clin Orthop Relat Res 2011;469(11):2992-4. Crossref

6. Musculoskeletal Infection Society. International Consensus on Periprosthetic Joint Infection. http://www.msis-na.org/ international-consensus/ [Erişim tarihi: 01.01.2016]

7. Della Valle C, Parvizi J, Bauer TW, DiCesare PE, Evans RP, Segreti J, Spangehl M, Watters WC 3rd, Keith M, Turkelson CM, Wies JL, Sluka P, Hitchcock K; American Academy of Orthopaedic Surgeons. American Academy of Orthopaedic Surgeons clinical practice guideline on: the diagnosis of periprosthetic joint infections of the hip and knee. J Bone Joint Surg Am 2011;93(14):1355-7. Crossref

8. Bedair H, Della Valle CJ. Aspiration and Serology Tests. In: Scuderi GR, editor. Techniques in revision hip and knee arthroplasty. New York: Elsevier Saunders; 2015. p.13-7.

9. Morgan PM, Sharkey P, Ghanem E, Parvizi J, Clohisy JC, Burnett RS, Barrack RL. The value of intraoperative Gram stain in revision total knee arthroplasty. J Bone Joint Surg Am 2009;91(9):2124-9. Crossref 
10. Ghanem E, Ketonis C, Restrepo C, Joshi A, Barrack R, Parvizi J. Periprosthetic infection: where do we stand with regard to Gram stain? Acta Orthop 2009;80(1):37-40.

11. Celasun B, Aksu A, Safalı M, Evren G, Günhan Ö, Finci R. Bir tanı yönetmi olarak 'Frozen Section' 1316 olgunun değerlendirilmesi. Ankara Patoloji Bülteni 1992;9(1);41-8.

12. Banit DM, Kaufer $\mathrm{H}$, Hartford JM. Intraoperative frozen section analysis in revision total joint arthroplasty. Clin Orthop Relat Res 2002;(401):230-8.

13. Stroh DA, Johnson AJ, Naziri Q, Mont MA. Discrepancies between frozen and paraffin tissue sections have little effect on outcome of staged total knee arthroplasty revision for infection. J Bone Joint Surg Am 2012;94(18):1662-7.

14. Tohtz SW, Müller M, Morawietz L, Winkler T, Perka C. Validity of frozen sections for analysis of periprosthetic loosening membranes. Clin Orthop Relat Res 2010;468(3):762-8. Crossref

15. Chatterjee S. Artefacts in histopathology. J Oral Maxillofac Pathol 2014;18(Suppl 1):S111-6. Crossref

16. Bergin PF, Doppelt JD, Hamilton WG, Mirick GE, Jones $A E$, Sritulanondha S, Helm JM, Tuan RS. Detection of periprosthetic infections with use of ribosomal RNAbased polymerase chain reaction. J Bone Joint Surg Am 2010;92(3):654-63. Crossref

17. Qu X, Zhai Z, Li H, Li H, Liu X, Zhu Z, Wang Y, Liu G, Dai K. PCR-based diagnosis of prosthetic joint infection. J Clin Microbiol 2013;51(8):2742-6. Crossref

18. Cazanave C, Greenwood-Quaintance KE, Hanssen AD, Karau MJ, Schmidt SM, Gomez Urena EO, Mandrekar JN, Osmon DR, Lough LE, Pritt BS, Steckelberg JM, Patel R. Rapid molecular microbiologic diagnosis of prosthetic joint infection. J Clin Microbiol 2013;51(7):2280-7. Crossref

19. Osmon DR, Berbari EF, Berendt AR, Lew D, Zimmerli W, Steckelberg JM, Rao N, Hanssen A, Wilson WR, Infectious Diseases Society of America. Diagnosis and management of prosthetic joint infection: clinical practice guidelines by the Infectious Diseases Society of America. Clin Infect Dis 2013;56(1):e1-25. Crossref

20. Schinsky MF, Della Valle CJ, Sporer SM, Paprosky WG. Perioperative testing for joint infection in patients undergoing revision total hip arthroplasty. J Bone Joint Surg Am 2008;90(9):1869-75. Crossref

21. Trampuz A, Hanssen AD, Osmon DR, Mandrekar J, Steckelberg JM, Patel R. Synovial fluid leukocyte count and differential for the diagnosis of prosthetic knee infection. Am J Med 2004;117(8):556-62.

22. Zimmerli W, Sendi P. Orthopaedic implant-associated infections. In: Bennett JE, Dolin R, Blaser MJ, editors. Principles and Practice of Infectious Diseases. Canada: Elsevier-Saunders; 2015. p.1328-40.

23. Deirmengian C, Hallab N, Tarabishy A, Della Valle C, Jacobs JJ, Lonner J, Booth RE Jr. Synovial fluid biomarkers for periprosthetic infection. Clin Orthop Relat Res 2010;468(8):2017-23. Crossref

24. Lenski M, Scherer MA. Synovial IL-6 as inflammatory marker in periprosthetic joint infections. J Arthroplasty 2014;29(6):1105-9. Crossref

25. Hoell S, Borgers L, Gosheger G, Dieckmann R, Schulz D, Gerss $\mathrm{J}$, Hardes J. Interleukin-6 in two-stage revision arthroplasty: what is the threshold value to exclude persistent infection before re-implanatation? Bone Joint J 2015;97-B(1):71-5. Crossref
26. Deirmengian C, Kardos K, Kilmartin P, Cameron A, Schiller $K$, Parvizi J. Diagnosing periprosthetic joint infection: has the era of the biomarker arrived? Clin Orthop Relat Res 2014;472:3254-62. Crossref

27. Bingham J, Clarke $H$, Spangehl $M$, Schwartz A, Beauchamp C, Goldberg B. The alpha defensing-1 biomarker assay can be used to evaluate the potentially infected total joint arthroplasty. Clin Orthop Relat Res 2014;472(12):4006-9. Crossref

28. Deirmengian C, Kardos K, Kilmartin P, Cameron A, Schiller $\mathrm{K}$, Parvizi J. Combined measurement of synovial fluid alphadefensin and C-reactive protein levels: Highly accurate for diagnosis periprosthetic joint infection. J Bone Joint Surg Am 2014;96:1439-45. Crossref

29. Deirmengian C, Lonner J, Booth RE Jr. The Mark Coventry Award: White blood cell gene expression: A new approach toward the study and diagnosis of infection. Clin Orthop Relat Res 2005;440:38-44.

30. ParviziJ, McKenzieJC, CashmanJP. Diagnosis of periprosthetic joint infection using synovial C-reactive protein. J Arthroplasty 2012;27(8 Suppl):12-6. Crossref

31. Wetters NG, Berend KR, Lombardi AV, Morris MJ, Tucker TL, Della Valle CJ. Leukocyte esterase reagent strips for the rapid diagnosis of periprosthetic joint infection. J Arthroplasty 2012;27(8 Suppl):8-11. Crossref

32. Gollwitzer $H$, Dombrowski $Y$, Prodinger PM, Peric M, Summer B, Hapfelmeier A, Saldamli B, Pankow F, von Eisenhart-Rothe R, Imhoff AB, Schauber J, Thomas P, Burgkart R, Banke IJ. Antimicrobial peptides and proinflammatory cytokines in periprosthetic joint infection. J Bone Joint Surg Am 2013;95(7):644-51. Crossref

33. Matsen Ko L, Parvizi J. Diagnosis of Periprosthetic Infection: Novel Developments. Orthop Clin North Am 2016;47(1):19. Crossref

34. Costerton JW, Stewart PS, Greenberg EP. Bacterial biofilms: a common cause of persistent infections. Science 1999;284(5418):1318-22.

35. Southwood RT, Rice JL, McDonald PJ, Hakendorf PH, Rozenbilds MA. Infection in experimental hip arthroplasties. J Bone Joint Surg Br 1985;67(2):229-31.

36. Cakmak S. Ortopedik biyomateryallerde bakteri biyofilm oluşturulması ve sonikasyonu için in vitro model: pilot çalıssma 23. Ulusal Türk Ortopedi ve Travmatoloji Kongresi 29 Ekim - 3 Kasım 2013, Antalya.

37. Della Valle C, Parvizi J, Bauer TW, Dicesare PE, Evans RP, Segreti J, Spangehl M, Watters WC 3rd, Keith M, Turkelson CM, Wies JL, Sluka P, Hitchcock K; American Academy of Orthopaedic Surgeons. Diagnosis of periprosthetic joint infections of the hip and knee. J Am Acad Orthop Surg 2010;18(12):760-70.

38. Ghanem E, Parvizi J, Burnett RS, Sharkey PF, Keshavarzi $\mathrm{N}$, Aggarwal A, Barrack RL. Cell count and differential of aspirated fluid in the diagnosis of infection at the site of total knee arthroplasty. J Bone Joint Surg Am 2008;90(8):163743. Crossref

39. Bedair H, Ting N, Jacovides C, Saxena A, Moric M, Parvizi J, Della Valle CJ. The Mark Coventry Award: diagnosis of early postoperative TKA infection using synovial fluid analysis. Clin Orthop Relat Res 2011;469(1):34-40. Crossref

40. Schäfer P, Fink B, Sandow D, Margull A, Berger I, Frommelt $\mathrm{L}$. Prolonged bacterial culture to identify late periprosthetic joint infection: a promising strategy. Clin Infect Dis 2008;47(11):1403-9. Crossref 
41. Della Valle CJ, Sporer SM, Jacobs JJ, Berger RA, Rosenberg AG, Paprosky WG. Preoperative testing for sepsis before revision total knee arthroplasty. J Arthroplasty 2007;22(6 Suppl 2):90-3.

42. Chryssikos T, Parvizi J, Ghanem E, Newberg A, Zhuang $\mathrm{H}$, Alavi A. FDG-PET imaging can diagnose periprosthetic infection of the hip. Clin Orthop Relat Res 2008;466(6):1338-42. Crossref

43. Parvizi J, Gehrke T, Chen AF. Proceedings of the International Consensus on Periprosthetic Joint Infection. Bone Joint J 2013;95-B(1):1450-2. Crossref
44. Dinneen A, Guyot A, Clements J, Bradley N. Synovial fl uid white cell and diff erential count in the diagnosis or exclusion of prosthetic joint infection. Bone Joint J 2013;95-B(4):5547. Crossref

45. Kapadia BH, Berg RA, Daley JA, Fritz J, Bhave A, Mont MA. Periprosthetic joint infection. Lancet 2016;387(10016):38694. Crossref 